\title{
Luigi Pirandello's Works in Lithuania: Why the Dialogue Did Not Take Place
}

\author{
GITANA VANAGAITE்
}

Abstract. Luigi Pirandello (1867-1936) was an Italian modernist writer and playwright who enriched literature with questions of modern identity as it relates to the contradiction between human consciousness and reality. Pirandello pondered questions of art and reality, mask and essence, life and form, and the fragmentation of a personality. In his works, he also foresaw what would later constitute the base of existential philosophy.

The reception of Pirandello's works in Lithuania has been limited, in part because of the small number of his works translated into Lithuanian - only a dozen short stories, two plays, and a novel.

The first more or less systematic and thorough introduction to the playwright and his works took place in 1934, when the Italian writer was awarded the Nobel Prize in Literature for his "bold and brilliant renovation of the drama and the stage." A few articles on Pirandello's creative principles appeared in the Lithuanian press. A Lithuanian poet, Kazys Binkis, translated the beginning of Pirandello's play, Sei personaggi in cerca d'autore (Six Characters in Search of an Author, 1921), and a writer, Kostas Korsakas, edited a book consisting of five novels, Pirmoji naktis ('First Night'). A Lithuanian translation of his novel, Il fu Mattia Pascal (The Late Mattia Pascal, 1904), and two plays, Sei personaggi in cerca d'autore and Enrico IV (Henry IV, 1922), came out during the Soviet period.

All translations were accompanied by a foreword containing basic biographical details about and introducing Pirandello's cultural, literary and creative life. Although Pirandello gets attention in Lithuanian university textbooks, no academic paper about him or his works has been published yet. There have been no translations of Pirandello's theoretical texts, his thoughts on the cultural situation, literature, and man at the beginning of the $20^{\text {th }}$ century, i.e., a volume of essays Arte e Scienza (Art and Science) written in 1908 or an important long essay, L'umorismo (On Humor), in which author also examines the principles of his own art. On the other hand, the literary reception of Pirandello's works has been supplemented by theater performances. Five plays of his were mounted and the play, Henry IV, was twice produced on Lithuanian theater stage.

The article examines why Pirandello's artistic ideas, which reached Lithuania during the second decade of the $20^{\text {th }}$ century, remained on the periphery and failed to influence the literary canon.

Keywords: Luigi Pirandello; Lithuanian literature; Lithuanian theatre; Modernism; reception; translation

DOI: http://dx.doi.org/10.12697/IL.2016.21.2.5 


\section{Introduction. Main Reference Points of Pirandello's Poetics}

Luigi Pirandello is considered a classic of Europe's Modernist movement in literature. He began his literary career in poetry in 1889; later he switched to writing prose and drama. His first attempts in prose, L'esclusa (The Outcast, 1901), short stories and a novel, were influenced by the verismo (Realism), an Italian literary movement of the second half of the $19^{\text {th }}$ century somewhat similar to the French Naturalism. Pirandello became famous for his novel $\mathrm{ll} \mathrm{fu}$ Mattia Pascal (The Late Mattia Pascal, 1904).

This novel marks the author's parting from Italian verismo and the birth of a Pirandellian "character". The main character of the novel, Mattia Pascal, even before his adventures begin, states his disinterest in reality and his inability to perceive himself as a whole person. In the first part of the novel, Pascal, as so many other famous characters of the beginning of the $20^{\text {th }}$ century, is a character "without any qualities," who simply drifts in life. After quarrelling with his wife and leaving home, Pirandello's character reads in the newspaper that the corpse of a suicide was found in his hometown, which his family identified as the missing Mattia Pascal. Feeling liberated, he decides to free himself from his unloved and unloving wife and cruel mother-in-law and start a new life.

Freedom, suddenly gained, should guarantee a new birth. However, this does not take place. By choosing the identity of another person, Adriano Meis, Pascal tries to build a new life, but soon he realizes that his new identity needs roots. The search for roots leads him to the realization that identity is based on civil law and a person's social status, which he does not have and cannot acquire. Pascal, tired of lies and acting out, once again simulates a suicide in order to get rid of Adrian Meis. After restoring his former name, regaining status and returning home, Pirandello's character discovers his wife living with another man. The deceased Mattia goes to the library to leave a record about his life. According to Nino Borsellino, a character is born from a dying person (see Borsellino: $200031-35)^{1}$ and the newly introduced permanent narrative time, which exists only in literary space, becomes a substitute for life.

In this novel, Pirandello raises philosophical and ethical issues that were particularly important at the beginning of the $20^{\text {th }}$ century. He asks: What is more important, an image of consciousness or the real world? What is the relationship between person's identity and social conventions or what is more important: life or form? These issues can be found on the novel's formal level

1 All quotes from Italian are translated by the author of this article, unless stated otherwise. 
as well. The first-person narratives of the real Mattia, the false Adriano and the deceased Mattia establish different perspectives and points of view, which destroy the role of the author as demiurge, a prophet of core values and social beliefs.

This main character's contradictory, fragmented, and fractured identity stood in opposition to the avant-garde movements (and Italian Futurism) that had just then begun to be established, which celebrated an individual and his vitality. Living in uncertainty, the only thing Mattia really knew was his own name: "One of the few things I knew for certain, in fact, perhaps the only thing, was this: that my name was Mattia Pascal." (Pirandello 1987: 6) Nevertheless, Pirandello's novel raises the question of why a name does not express a person's true inner reality and his identity.

The author returned to this tragic and grotesque aspect of human experience four years later, in his famous 1908 essay L'umorismo, dedicated to the memory of a librarian, Mattia Pascal ${ }^{2}$. The essay's theoretical aim, to define "a humorous art," is associated with the writer's specific aesthetic experience and practice. The two-part text can be read not only as a document of Pirandellian poetics, but also as "a strict parting from Benedetto Croce's Estetica (1902) that reigned at the time and which Pirandello regarded as too abstract, i.e., unable to provide effective parameters of behavior and evaluation for either the artist or the critic." (De Caprio, Giovanardi 1999: 518-519)

In the first part of the essay, Pirandello discusses the best examples of humorous literature from the late Middle Ages to Fyodor Dostoyevsky. In the second, more theoretical part, the author provides an important divide between "comic" and "humorous" art that can be applied to all his works. This divide calls for a broader context that integrates the motives of life and form or mask, interrelated by the principle of contrast.

According to Pirandello, the subject, who is forced to enclose his life into a form, cannot find a harmonious balance between his desires and his intellect. Therefore, he has to wear a mask, which helps to perform the roles entrusted to him by society, or a role authorized by his own moral ideals.

A human being must choose whether to play the hypocrite and passively accept the priority of form, or to deliberately and auto-ironically experience the divide between life and form. In this case, a constant reflection, determining a certain distance between the subject and his own gestures, is established. A

2 The dedication in the 1920 edition is missing. According to Borsellino, Pirandello wanted to highlight the objectivity of his study on the concept of comedic art by eliminating every opportunity to link the essay with his own poetics (Borsellino 2000: 38). 
person learns to live by observing and perceiving oneself and others through a reflexive, painful, remorseful, ironic, wordy, and humorous detachment.

Pirandello notes that comic art, which originates from the contrary experience caused by laughter, lacks deliberation. On the other hand, humorous art is described by the contrary feeling caused by deliberation. The perception of why a person or a situation is the opposite of what it should be is determined by deliberation. Therefore, laughter is complemented by painful feeling of pity. Pirandello says that deliberation, characteristic to humorous art, is an active position of author's critical consciousness.

\section{The Cultural Situation in Lithuania, Pirandello and the "Humorous Art"}

The first Lithuanian acquaintance with Italian writer and playwright took place in 1928. That year the State Theater director, Borisas Dauguvietis, mounted Pirandello's play, Cosi è (se vi pare) (Is It So (If You Think So) ${ }^{3}, 1917$ ), which Italian critics described as the grand parable (Enciclopedia 1997: 811) ${ }^{4}$. The play, based on Pirandello's novel La signora Frola e il signor Ponzasuogenero, was written in 1915 and first performed in Milan's Olimpia Theatre on June $18^{5}$. The time when the play was written coincided with the First World War and an event in Pirandello's personal life - his son Stefano was in Austrian captivity.

Pirandello considers the problem of man's connection to reality by confining the play's action, based on provincial rumors, to the private apartment of Councillor Agazzi. The play tells a story about Ponza, who has just moved into the town with his wife and mother-in-law, the family's disagreements, and their search for truth. Ponza, the center of all gossips in town, is pictured as a monster, who does not allow Mrs Frola, his mother-in-law, to see her own daughter. The Councillor goes to see the Prefect in order to find official documents that would allow him "to solve this mystery and find the truth." This desire is mocked by Lamberto Laudisi, who represents the skeptical

3 The title of the play, among other variations, sometimes is translated as Right You Are (If You Think So).

4 "I finished my three-part parable Cosi è (se vi pare)," wrote Pirandello to his son Stefano on April 18, 1917 (http://spazioweb.inwind.it/letteraturait/opere/pirandello02.htm, 6.12.2016).

5 After the premiere Pirandello wrote to his sister Lina: "It was a really big success not because of all the applauses but because of the confusion and bewilderment and frustration and shock diabolically induced to the public. I enjoyed it so much!” (http://spazioweb.inwind.it/letteraturait/opere/pirandello02.htm, 6.12.2016) 
dimension in the play. He defends the privacy of recent arrivals to the town and expresses an opinion on the impossibility of knowing one other and the truth in general.

Pirandello shows how each character fights for their inner truth, and how that fight does not allow them to understand one another. Mrs Frola does not accept the death of her daughter killed four years ago (a reference to real earthquake that took place in Marsica in 1915) and sees her son-in-law's second wife as her own daughter. Ponza, while protesting against the intrusion into his private life and the interrogation conducted by Councillor Agazzi, is forced to reveal the terrible truth - that Mrs Frola has gone mad. The mother-in-law, upon learning what people think about her, says that it is Ponza who is insane. And Giulia presents herself as Ponza's second wife and Mrs Frola's daughter. Thus, "the truth" of the matter remains a mystery.

Although Pirandello's play takes place inside a private apartment, the paradoxical, grotesque and irrational jabbering of everyday bourgeois life takes on a universal dimension. The context of the First World War's massacres reinforces the feeling of uncertainty, which is offset by creating new mystification. According to Borsellino, the war context becomes a catalyst for a Pirandellian character who seems to be trying to return to his original situation and find his own authenticity. However, he succeeds in doing this only temporarily. Unable to withstand the suffering caused by war and life itself, he again becomes a character who has isolated himself in the imagined space of illusions (Borsellino 2000: 76). The illusory life in the play is supported and the idea of the Pirandellian character is reinforced by the playwright's consistently developed psychological sado-masochistic solidarity mechanism, filled with brutal compassion.

How was this parable, embedding the poetics of comedic art and marking the culmination of a Pirandello character's evolution (see Borsellino 2000: 77), received by the Lithuanian theater audience and critics in 1928, and what do theater critics think of it today?

The premiere of Cosi è (se vi pare) took place on May 26, 1928. At the time, the professional Lithuanian theater ${ }^{6}$ and directing were taking their first

6 Latvian theater was formed much earlier. By 1923-1925, new theaters developed in Latvia spread symbolism (Biruta Skujeniece), expressionism (Jurijs Jurovskis and Janis Zarins) and poly-stylistic theater principles (Eduards Smiļgis) (Aleksaitè 2004: 8). Meanwhile, the Estonian theater critic Luule Epner says that “[...] Estonian theater, even more than literature, is characterized by leaps and short modernism "outbreaks," i.e., it was not developing uniformly. The first quests for modern style in the Estonian theater are observed in the mid-20s in the plays by 
steps. Directors faced a difficult task: how to conquer an audience that knew little about theater and attended only reluctantly. The solution was to mount as many performances as possible, thus making directors' work pace almost insane. "Borisas Dauguvietis broke all the records, by releasing the most eleven out of fourteen - productions in a period of seven months in 1924." (Aleksaite 2004: 9)

Despite such efforts, the Lithuanian theatre "of the 20s remained isolated from Western Europe and Russia's theatrical innovations and experiments" (Aleksaite 2004: 9). The biggest role in reducing the isolation between Lithuanian theater and audience was played by Dauguvietis, who jumped into a never-ending carousel of performances and found the strength and desire to experiment and try out different styles and genres. "The director was the first to dive into modern theater; he created it." (Aleksaite 2004: 10) The most modern of Dauguvietis's productions was Pirandello's Così è (se vi pare).

The director, who understood the play's complexity and simplicity, schematized and standardized the stage set and the actor's roles. He dressed each sex in a single style, used only black and white, and all of the characters were seated using a pyramid principle with their profiles to the audience (see Aleksaite 2004: 12). The set was created by an architect, Vladimiras Dubeneckis, who had gained some set building experience while living in Germany. He arranged the stage by precise mathematical and geometrical principles: "The stage was bare except for the black vertical panels and a few stairs. [...] Two different colors - black and white - emphasized the spare set, built on the principle of contrasts; it was linked with the geometric expression of the costumes." (Bitinaité-Širvinskienè 2006: 150)

The production ran very briefly. It was received with hostility; the audience had a difficult time understanding such a confusing and strange play. The performance felt obscure, not only because of its content, but also because of its artistic set solutions. "It [the audience] was not used to these surprising and hardly comprehensible innovations in theater." (Aleksaite 2004: 12) Although Balys Sruoga, a poet, playwright and theater critic, was particularly enthusiastic about the premiere and five days after the opening wrote: "Our normal theater had disappeared somewhere; it plunged down into the earth. [...] Instead, during entire premiere an unknown good European theater starred for us ..." (Sruoga 1928: 4)

expressionists (and symbolists) [...]. Plays by Luigi Pirandello did not make it to the stage at all." (Epner 2004: 36). All quotes were translated by Dalia Cidzikaitè, unless stated otherwise. 
VANAGAITE்

Another mounting of Pirandello's play in Lithuania did not take place until 1944. On March 25 of that year, the director of Panevėžys Drama Theatre, Juozas Miltinis, directed Enrico IV (Henry IV, 1922). Miltinis studied theater in Paris in 1932-1938, and while he was there he visited London. He returned to Lithuania with a clear directorial vision of intellectual and conceptual theater, ${ }^{7}$ however, this type of theater did not exist in Lithuania at the time. In Panevėžys he founded a theater-studio, based on consistent workshops and directing and overseen by one director, Miltinis. Pirandello's tragedy, Enrico $I V$, was Miltinis's first production in young theater's repertoire. The play was produced at a particularly difficult time of war, working with young actors with almost no theater experience.

The tragedy is about a hero who thinks he is the $11^{\text {th }}$-century German Emperor, Henry IV. Even though memory returns to him twelve years later, he continues to pretend to be insane because he cannot face the tragic reality.

Pirandello creates the world of Enrico IV as a complex carnival, where all the characters see themselves as actors, as conscious marionettes. The story, consciously played, becomes Henry IV's only option to escape from present uncertainties, because history has already taken place; it is a reality with all the questions answered. Miltinis's production was not successful. The play, too intellectual and difficult to understand, was performed only six times. The actor Stasys Paska recalls that "only two tickets were sold to the second or third performance. Even now I see empty chairs before my eyes" (cit. from Sakalauskas 1999: 171). Another actor ir Miltinis's troupe, Donatas Banionis, who was taking his first steps on the stage at the time, adds:

Perhaps the biggest challenge for all of us at the time was Luigi Pirandello's Henry IV, which premiered in the spring of 1944 . We, the workers' children, were to become characters of an epoch and fabric of life completely unfamiliar to us. Who and what kind of people were those long-ago Frenchmen and Italians; what to do to make them become alive on our young theater's stage? Make them become alive so the audience would believe in them? I got to play the young Marquis. Yes, I, like my other colleagues, was taught to behave at the table; I knew that it was inappropriate to leave a spoon in a glass and put your elbows on the table. But it wasn't enough to become a Marquis! My Marquis did not know where to put his hands, how to walk, or what intonation to use ... Frankly speaking, not only did I not know these things - we did not

\footnotetext{
7 "I created my theater project, a vision, an idea in my consciousness," Miltinis said
} (Sakalauskas 1999: 151). 
understand the play at all, which Miltinis himself translated from Italian ${ }^{8}$, hoping that world dramaturgy would become an integral part of the Lithuanian theater. (Banionis 2004: 26-27)

For Miltinis, Pirandello's tragic grotesque was an opportunity to approach existential topics, to raise questions about the relationship between a human being and his environment, and to think about the reasons why a person chooses the world of illusions over reality. These existential problems and the individual's confrontation with a hostile world, which Pirandello explores through Henry IV's carnivalesque insanity, felt very painful and relevant in 1944. But the Lithuanian audience, tired of the German occupation, wanted lighter and less complicated shows on stage.

Critics, however, clearly grasped the main idea of the play: "The play frequently puts our audience in an unpleasant position; it exposes one and only one truth: hold on to your truth as hard as you can, so you do not have to be a hypocrite and convince yourself of your belief in that hypocrisy." (Quoted from: Zabarauskas 1966: 22) On the other hand, critics had to note that "the ideological motives of the tragedy outweigh the actors. Out of thirteen characters, almost no one "had anything to do" [on the stage]. Therefore an actor loses and is left with very little space to express himself." (Z.U. 1944)

Although Miltinis's Enrico IV stirred critics' minds and aroused their curiosity, the play was considered too forward, a misunderstood and failed performance 9 . On the other hand, it became an important argument in an everlasting debate about the essence of national Lithuanian theater, since it was seen as a counterweight and alternative to "Russian naturalism," which dominated Lithuanian theater at the time. In those times, theater tradition "had avoided clearly pronounced stylization, poetics, a particular "spiritualization" and elevation: the audience was forced to see things happening on stage as concrete rather than an illusory reality that shifts between dream and reality." (B.K. 1944: 118)

8 Prof. Rita Aleknaitè-Bieliauskienè noted in her paper "Lithuanian Cultural Life Paradigm during the Nazi Occupation (Cases of Panevėžys and Šiauliai)" presented at the international conference "The War in Literature and Culture" (23 October, 2015) that Miltinis translated this play from French and not Italian.

9 Miltinis himself remembered the production: “[...] In 1944, for the first time I directed Pirandello's Henry IV, a very difficult, philosophical, and intellectual play. After the first two performances, which drew a number of spectators, somebody spread a rumor that there's nothing to see and all the subsequent performances were performed in an empty theater ... Of course, we were able to enrich the intellectual repertoire, so dear to me, only gradually." (Quoted from Sakalauskas 1999: 171) 
Lithuanian theater returned to Pirandello's Enrico IV in 1997. The tragedy was mounted at the Šiauliai Drama Theatre by the director Rolandas Atkočiūnas. The premiere took place on November 29. "This play is not only and perhaps not as much a treatment of the specific text written in 1922, but more a theatrical paraphrase of relativism motives characteristic of Pirandello's poetics." (Didžgalvis 1997: 19) In consequence, "the director consistently ignores the plot of the play and presents a theatrical projection of madness. [...]. At the very beginning of the performance, the stage is turned inside out like a glove for the audience to see its dirty and dusty lining. [...] Its topic is the very process of acting, play-acting, theatrical ambiguity and the external and internal transformations of a human being who acts. Its subject is the dethroning of theater as an illusory, false, and always ambiguous world." (Didžgalvis 1997: 19)

The explicit conditionality of the play was not particularly attractive to the audiences and that was noticed by theater critics: "The director's language is so strong that it upstages the original story about the gentleman who fell from a horse, hurt himself, and lost his mind. [The play] rejects historical realities and parallels [...]. The relationship line between Henry and Matilda is weakened. Why did we come here? the audience will exclaim. For theater, the director will answer, after all, you came to see a play, and not Pirandello." (Jauniškis 1997: 5) The theatrical madhouse created by Atkočiūnas did not turn into a theatrical event, it remained a mere fact.

Another Pirandello play, Sei personaggi in cerca d'autore (Six Characters in Search of an Author, 1921), directed by Vytautas Čibiras in 1976, also met with notably unfavorable criticism by both critics and audiences. Its premiere took place in the Kaunas Drama Theatre on April 18. A theatre critic, Irena Aleksaitè, who wrote a review about theater's season, noted that:

In my view, Pirandello's philosophic-aesthetic concept, related to a very complex mutual interaction between art and reality, is not apparent; and the aesthetic discussion, wrapped in several layers of dramatic structure, does not take place. I think that the performance by the Kaunas theater actors is a simplified solution to the play with quite oddly arranged notional stresses. [...]. The author's significant themes of art's essence and its role, the limits and possibilities of reality's artistic interpretations are left hanging in the air [...]. (Aleksaitè 1976: 3)

Another theater critic, L. Samuolis, notes that the director could not find a suitable artistic solution and lost control of play's complex problems: 
And yet, despite some undeniable successes, the director failed to create a forceful play as a whole. He could not decide which of many options offered by Pirandello he wanted to emphasize. The actors, lacking a clear goal, got lost in a complex script and therefore, the most incisive conflict situations were sugarcoated. (Samuolis 1976: 4)

In 1995, the director Danguolè Bagdanskaite directed Pirandello's one-act comedy Bellavita, adapted from the novel L'ombra del rimorso, in the Small Theater of Vilnius. And in 2008, a sketch of the play Questa sera sirecita a soggetto, directed by Arvydas Dapšys, was performed at the Arts Factory. Due to the lack of funds only part of the play was mounted. The sketch inaugurated a new theater space in Lithuania, the Arts Printing House, using Pirandello's improvisation idea to highlight the aim for reforms: "It is not a reaction to a specific situation in Lithuanian theater; rather it is an internal reform, which we all must periodically perform on ourselves," the director said. Unfortunately, the sketch was never mounted into a full play. It turned out to be yet one more not fully-realized possibility.

\section{Towards Conclusions, or Assumptions for an Intercultural Dialogue}

Translations are one of the most important preconditions for intercultural dialogue. Problematics in translations open up a wide field for theoretical reflections. In addition, translations play a crucial role in national cultures' development, as translated literature provides new points of reference, affects literary genres, and changes cultural imagination. Translations are not so much a matter of two languages as they are a matter of two cultures, which are based on different stylistic and literary canons: "A translator must not only control the language, but everything that goes beyond the language, i.e., an entire culture, an entire world and an entire way of understanding the world." (Fruttero, Lucentini 2003: 60)

An important turning point in translation studies took place after the 1970s, when André Lefevere, following James Holmes, announced that he "would like to propose the name 'translation studies' for the discipline which concerns itself with the problems raised by the production and description of translations." (Lefevere 1978: 234) The decline of linguistic models has occurred especially since the 1980s, when translation study was characterized by the so-called "cultural turn" (Bassnett and Lefevere, 1990). Influenced by cultural studies, translation study has put more emphasis on the cultural aspects of translation: 
the focus is on social and cultural practices, on the relationship between translation behavior and socio-cultural factors. This cultural turn facilitated an understanding of a translation as an intercultural dialogue, which can, in turn, be combined with various other disciplines.

Pirandello's theater productions and literary translations in Lithuania can be analyzed within the framework of intercultural dialogue. Here, I would like to leave aside linguistic problems of translations and only mention that in 1961, a collection of 22 short stories by Pirandello, Juodoji skraiste ('The Black Cloak'), was published. The stories were translated from Italian by Eduardas Viskanta. He also translated Pirandello's plays, Sei personaggi in cerca d'autore (1973) and Enrico IV (1986). In 1969, Juozas Naujokaitis translated Pirandello's novel Il fu Mattia Pascal from Russian.

Pirandello himself referred to the problems of a complicated translation and its functioning in a certain cultural environment. In his play, Sei personaggi in cerca d'autore, Father says:

But don't you see that the whole trouble lies here. In words, words. Each one of us has within him a whole world of things, each man of us his own special world. And how can we ever come to an understanding if I put in the words I utter the sense and value of things as I see them; while you who listen to me must inevitably translate them according to the conception of things each one of you has within himself. (Pirandello 1922)

Father's words emphasize the concept of inner reality, paying attention to challenges presupposed by cultural transposition ${ }^{10}$. No literary work can be artificially transferred to different cultural environment, and the host culture has to be ready to accept and understand certain cultural values and concerns.

This review of Pirandello's reception in Lithuania shows that the cultural distance, covering civilization, intellectual and mental differences, aesthetic and philosophical orientation, and finally the language in which all things mentioned above are embedded, may not always be overcome. Or the desire to overcome it presupposes a direct influence, as happened with the play Generaline repeticija ('The Dress Rehearsal'), by the Lithuanian avant-garde poet and playwright Kazys Binkis, who was influenced by Pirandello's Sei personaggi in cerca d'autore.

Translations play a significant role in shaping the development of a national literature. Their selection highlights a literature's maturity and the level of

10 This article will not include a discussion of the cultural transposition proceedings such as omission, neutralization and equivalence. 
Luigi Pirandello's Works in Lithuania

its development. The analysis of Pirandello's translations and especially his theater productions in Lithuania, demonstrate that although they were not always accepted, they played a crucial role in elevating Lithuanian culture.

\author{
Gitana Vanagaitè \\ gitana.vanagaite@leu.lt \\ Lietuvos edukologijos universitetas \\ Lietuvių ir lyginamosios literatūros katedra \\ T. Ševčenkos 31-211 \\ LT-03111 Vilnius \\ LIETUVA / LITHUANIA
}

\title{
Bibliography
}

Aleksaitè, I. 1976. „Grūdas prie grūdo” (Apie praejjusị teatro sezoną). - Literatūra ir menas, rugpjūčio $28,3$.

Aleksaitè, I. 2004. „Pirmieji modernizmo blykstelejimai lietuvių prieškario teatre 1920-1929 m." [The First Spars of Modernism in Pre-War Lithuanian theatre (1920-1929)]. - Menotyra, t. 37, nr. 4, 8-13.

B. K. 1944. „Vieneri metai dramos teatre”.- Küryba, 2, 118.

Banionis, D. 2004. Memuarai. Vilnius: Versus aureus.

Bassnett, S., Lefevere, A. 1990. Translation, History and Culture. London: St. Martin's Press.

Bitinaitè-Širvinskienè, R. 2006. „Dailininkas ir modernumo provokacijos tarpukario teatre." [The Set Designer and the Provocation of Modernity at the Theatre of the Interwar]. - Acta Academiae Artium Vilnensis, 43, 147-164.

Borsellino, N. 2000. Ritratto e immagini di Pirandello. Roma-Bari: Editori Laterza.

De Caprio, V., Giovanardi, S. 1999. Letteratura italiana. Storia. Autori. Testi. Milano: Einaudi scuola.

Didžgalvis, V. 1997. „Pirandelizmo parafrazès”: [L. Pirandello pjesė „Henrikas IV” Šiaulių dramos teatre, režisierius R. Atkočiūnas]. - Šiaulių kraštas, gruodžio 18, 19.

Enciclopedia Garzanti della Letteratura. Milano: Garzanti Editore.1997.

Epner, L. 2004. „Apie modernizmą estų teatre” [On Modernism in Estonian Theatre]. Menotyra, t. 37, nr. 4, 35-38.

Fruttero, C., Lucentini, F. 2003. I ferri del mestiere. Manuale involontario di scrittura con esercizi svolti. Torino: Einaudi.

Jauniškis, V. 1997.„Drastiška režisieriaus ir dramaturgo studija apie teatrą ir jo pamišèlius”: [L. Pirandello pjesė „Henrikas IV” Šiaulių dramos teatre, režisierius R. Atkočiūnas]. - Lietuvos rytas, gruodžio 9, priedas „Mūzų malūnas”, 5.

Lefevere, A. 1978. "Translation studies. The Goal of the Discipline”. - Holmes, J. S., Lambert, J., van den Broeck, R. Raymond (Eds.). Literature and Translation. Louvain: ACCO 
VANAGAITE

Pirandello, L. 1987. The Late Mattia Pascal. Translated by Nicoletta Simborowski. London: Dedalus.

Pirandello, L. 1922. Six characters in search of an author. English version by Edward Storer. New York: E. P. Dutton. http://www.eldritchpress.org/lp/six.htm

Sakalauskas, T. 1999. Miltinio apologija. Vilnius: Scena.

Samuolis, L. 1976. „Pirandelo variantų labirintuose”. - Kūrybos savaitè („Kauno tiesos" priedas), gegužès 13, 3, 4 .

Sruoga, B. 1928. „Nepaprasta premjera”-- Lietuvos aidas, gegužès 31 d.

Zabarauskas, V. 1966. Panevežio dramos teatras. Vilnius: Mintis.

Z. U., 1944. „L. Pirandello ateina ị mūsų teatrą".- Naujoji Lietuva, 1944. IV. 16. 